Int. J. Dev. Biol. 49: 745-759 (2005)

doi: $10.1387 / \mathrm{ijdb} .051991 \mathrm{fw}$

\title{
Gene network analysis in plant development by genomic technologies
}

\author{
FRANK WELLMER and JOSÉ LUIS RIECHMANN* \\ Division of Biology, California Institute of Technology, Pasadena, CA, USA
}

\begin{abstract}
The analysis of the gene regulatory networks underlying development is of central importance for a better understanding of the mechanisms that control the formation of the different cell-types, tissues or organs of an organism. The recent invention of genomic technologies has opened the possibility of studying these networks at a global level. In this paper, we summarize some of the recent advances that have been made in the understanding of plant development by the application of genomic technologies. We focus on a few specific processes, namely flower and root development and the control of the cell cycle, but we also highlight landmark studies in other areas that opened new avenues of experimentation or analysis. We describe the methods and the strategies that are currently used for the analysis of plant development by genomic technologies, as well as some of the problems and limitations that hamper their application. Since many genomic technologies and concepts were first developed and tested in organisms other than plants, we make reference to work in non-plant species and compare the current state of network analysis in plants to that in other multicellular organisms.
\end{abstract}

KEY WORDS: gene network, development, transcriptional regulation, gene expression, plant

\section{Introduction}

The execution of developmental processes in multicellular organisms, plants as well as animals, is largely dependent on the cellular capacity for differential gene expression (reviewed in: Scott, 2000). That capacity (or, in other words, the developmental program of an organism) is hardwired and encoded in the genome (Davidson, 2001, Davidson et al., 2002, Revilla-i-Domingo and Davidson, 2003), in the form of cis-regulatory sequences that determine when, where and how genes are expressed, of transcription factors and transcriptional co-regulators that act on those sequences and of other types of regulatory proteins or RNAs that modify or modulate the activities of other proteins or genes. The development of genomic technologies and the ensuing availability of various types of large-scale datasets (from the genome sequence of an ever increasing number of organisms to gene expression or protein-protein interaction maps, Vidal, 2001) have opened the possibility of studying the transcriptional regulatory networks that control development at a global level. However, our current understanding of how the genome is brought to play throughout the developmental program or the different life stages of any eukaryotic organism is in the best of cases (such as the yeast Saccharomyces cerevisiae) still rudimentary and in plants, vastly lacking. Classic genetic and molecular approaches have identified many regulators of developmental processes and organized them in genetic pathways, circuits or models underlying such processes - and those regulators have frequently turned out to be transcription factors. Among many notable examples of the success of developmental genetic studies in plants, and in Arabidopsis thaliana in particular, are the ABC model of floral organ identity determination (Lohmann and Weigel, 2002, Jack, 2004) and our current understanding of the mechanisms for root patterning and cell identity determination (Birnbaum and Benfey, 2004, Montiel et al., 2004), control of flowering time (Boss et al., 2004, Henderson and Dean, 2004, Putterill et al., 2004, Sung and Amasino, 2004), or establishment of lateral organ polarity (Bowman et al., 2002, Engstrom et al., 2004), to name a few (see also reviews in this issue, for those and other examples). All these processes are largely controlled by a variety of transcription factors, but in no single case we have a deep understanding of, for instance, the genes that are controlled by each of the factors and the mechanisms by which they exert such regulation.

Genomic approaches now offer the possibility of transforming those (small) genetic circuits or pathway diagrams into larger

Abbreviations used in this paper: AP, APETALA; AG, AGAMOUS; CAL, CAULIFLOWER; Dex, dexamethasone; GR, glucocorticoid receptor; LD, long day; PI, PISTILLATA; SD, short day; SEP, SEPALLATA.

\footnotetext{
*Address correspondence to: Dr. José Luis Riechmann, Division of Biology 156-29, California Institute of Technology, Pasadena, CA 91125, USA. Fax: +1-626-449-0756. e-mail: jriechma@caltech.edu
} 
networks, eventually encompassing all of the genes of the genome that take part in a given process. In this review, we focus on genomic analyses of transcriptional regulatory networks in plant development - but not so much on the developmental processes or pathways per se, as they are the topic of other reviews in this issue. We first provide a brief overview of the different types of global data (and of the methods to acquire them) that are necessary in order to study, at a molecular level, transcriptional regulatory networks: comprehensive lists of parts (cis-regulatory elements, genes) and of the interactions between them (proteinDNA binding data, protein-protein interactions). Since many genomic technologies and concepts were first developed and tested in organisms other than plants, yeast in particular, we make reference to work in non-plant species, also highlighting a few landmark studies that opened new avenues of experimentation or analysis that will be of use in, or influence, studies in plants. There are, however, specific problems and caveats for applying genomic technologies to study regulatory networks in multicellular organisms (compared to the single-celled yeast) - we review those, with some examples from non-plant species and an emphasis on the tools and strategies that have been, or are being, developed in plants. It has become a common realization in the genomics field that the combined analysis of more than one dataset or type of data is much more powerful than the analysis of single datasets. This is in part the result of the uncertainty that is associated with such genome-wide datasets (for a review on this topic, see: Grunenfelder and Winzeler, 2002), but also of the underlying biology (for example, that an increased number of genome sequences of selected organisms at appropriate evolutionary distances augments the usefulness of phylogenetic footprinting to identify potential regulatory sequences). The combination of different datasets is essential for network definition and, eventually, modeling. We thus review cases where different genome-wide datasets (either within one species or across species) were combined or analyzed together. Lastly, the principal focus of this review is about the current status of genomic studies on plant developmental networks. We review examples on $\angle E A F Y$ and floral meristem determination, on floral organ identity genes, on root development and on the cell cycle. In some of those areas, flower development in particular, there have been interesting efforts to construct discrete dynamical network models by deriving and combining logical rules from available experimental data (primarily, genetic interactions and expression patterns of the known regulators), but we chose not to focus on those studies, as for the most part they currently fall outside of the genomic perspective that we concentrate on (but see, for example, Espinosa-Soto et al., 2004).

\section{Experimental approaches for gene network analysis in development}

The foundation for the application of genomic technologies for the study of development has been laid by the deciphering of the genomes of several key model organisms. This foundation was further strengthened by the experimental characterization of the transcriptional units in a genome, a necessary work considering the inaccuracies and difficulties for $a b$ initio gene prediction in eukaryotic genomes. Initial efforts for the characterization of transcriptional units were based on ESTs, large-scale full-length
cDNA cloning, Serial Analysis of Gene Expression (SAGE), Massively Parallel Signature Sequencing (MPSS) and RACEPCR. More recently, approaches that are based on whole-genome DNA microarrays, in which the genome of interest is represented in its entirety in a tiled fashion, have been used for Arabidopsis (Yamada etal., 2003), Drosophila (Stolc etal., 2004) and the human genome (Kapranov et al., 2002, Rinn et al., 2003, Bertone et al., 2004, Kampa et al., 2004). In addition, public databases for different types of biological information, from transcription factor binding sites to gene ontology predictions, or the development of software tools for the prediction of cis-regulatory elements, aid tremendously in the analysis of the large datasets obtained by genomic technologies.

The genome-wide technologies that are currently available for the analysis of gene networks in development include: gene expression profiling using DNA microarrays, comparative analysis of promoter sequences of genes with similar expression profiles, phylogenetic footprinting and genome-wide location studies for DNA binding proteins using promoter (or whole genome) microarrays, or ChIP/chip experiments, (to elucidate the transcriptome and promoterome maps); a variety of reverse genetic methods for perturbation experiments; and protein-protein interaction technologies (yeast 2-hybrid, MS-based methods, etc.). These methods have been reviewed elsewhere (Riechmann, 2002) and therefore will not be described in detail here; rather, we illustrate with some examples how they are currently being used for the analysis of development.

As genome sequencing projects have coincided with the invention of microarray technology, gene expression profiling is to date the predominant approach for the analysis of development by genomic technologies. As a consequence, our current understanding about the regulatory networks underlying development is somewhat biased, for we have a rapidly increasing knowledge about patterns of and changes in, gene expression but little insight into the processes that occur post-transcriptionally. As indicated above, however, the results of many detailed studies on the genetic mechanisms underlying development have demonstrated that the regulation of gene expression is the central control point for most, if not all, developmental processes (Scott, 2000, Reinke and White, 2002).

One of those studies focused on the specification of the endomesoderm of the sea urchin embryo. Davidson and coworkers have delineated a gene network controlling this process that is comprised of more than 40 genes, most of which encode transcription factors (reviewed in: Davidson et al., 2002, Revillai-Domingo and Davidson, 2003, Oliveri and Davidson, 2004). The regulatory interactions between the network components were determined by large-scale perturbation experiments, in which the expression of individual genes was altered and the effect on the expression of other genes in the network was then determined by quantitative RT-PCR. These experiments led to the prediction of cis-regulatory interactions among the network components and many of these predictions have been confirmed subsequently by independent methods.

Although most of this work was done without the use of genomic technologies, it nevertheless outlines an overall strategy that can be successfully used for the study of gene networks by genome-wide approaches, as demonstrated by ldeker et al. for the yeast galactose metabolic network, which is under transcrip- 
tional control by GAL4p (Ideker et al., 2001, Ideker, 2004). The strategy aims, in a first step, at identifying the components of a regulatory network (genes, proteins, other regulatory molecules -such as small RNAs-, cis-regulatory sequences), which, because of previous genetic results, might be partly assembled into a "scaffold" for the network of interest. This is followed by an analysis of the molecular interactions between the components and by perturbation experiments to explore regulatory interactions, using whole genome assays to detect global responses. Integration of the resulting separate data types might then lead to expanded and corrected models, compared to those known at the beginning of the process (for a detailed example of this type of work, see Ideker et al., 2001).

Since the spatial and temporal expression patterns of genes can be indicative of their role in development, a good starting point for the identification of network components is to determine gene expression patterns of all genes of an organism at all stages of development (Reinke and White, 2002). Such large-scale gene expression studies are being performed for Drosophila (Arbeitman etal., 2002), C. elegans (Hill etal., 2000, Jiang etal., 2001, Baugh et al., 2003), mouse (Zhang et al., 2004) and Arabidopsis (http:/ /web.uni-frankfurt.de/fb15/botanik/mcb/AFGN/atgenex.htm). Cluster analysis of the microarray data obtained in this type of experiments can be used to identify groups of genes with similar expression patterns during the course of development. These coexpressed genes are good candidates for genes involved in the same developmental processes and are potentially co-regulated, i.e. they might be under the control of the same transcriptional regulators.

The data obtained in these studies now serve as a baseline for a more detailed analysis of gene expression in certain organs, tissues or cell-types. These studies frequently make use of mutants, in which the developmental process of interest is disrupted. For example, patterns of gene expression during mesoderm development of Drosophila were analyzed by comparing the gene expression profiles of wild-type embryos with that of twist, a mutant that does not develop a mesoderm (Furlong et al., 2001). In this study, hundreds of genes were identified that might have stage-specific functions during mesoderm development.

Another elegant example for a gene expression profiling experiment leading to the identification of genes involved in a specific developmental process comes from the analysis of stomatal development in Arabidopsis. By forward genetics, Bergmann et al. have identified $Y O D A$, which encodes a mitogen-activated protein kinase kinase kinase (Lukowitz et al., 2004), as a key regulator of stomatal development (Bergmann et al., 2004a). Loss-of-function alleles of YODA lead to a dramatic increase in the number of guard cells compared to wild type. In contrast, guard cells are absent in transgenic lines expressing a constitutively active version of YODA. In order to identify additional genes involved in stomatal development, the gene expression profile of the yoda mutant was compared to that of the transgenic plants using wild-type plants as a common reference. This experiment resulted in the identification of roughly 200 candidate genes and a large-scale reverse genetics screen confirmed subsequently the importance of some of these genes for stomatal development (Bergmann et al., 2004a).

While the approaches described above lead to the identification of probable components of the gene networks controlling development, they do not reveal the regulatory interactions between these components. The identification of cis-regulatory elements serving as input sequences for higher-level network components allows a deeper understanding of the hierarchical orders of a gene network. Databases such as TRANSFAC (http:/ /www.gene-regulation.com/), or the plant-specific data repositories PLACE (http://www.dna.affrc.go.jp/PLACE/) or PlantCARE (http://oberon.fvms.ugent.be:8080/PlantCARE/index.html) (Lescot et al., 2002) contain information on known cis-regulatory elements or transcription factor binding sites (reviewed in Rombauts et al., 2003). The information in these databases can now be used to systematically analyze the regulatory regions of co-expressed genes identified by microarray experiments. For example, by using the information on plant cis-regulatory elements available in the PLACE database, Nemhauser et al. identified regulatory elements that are significantly enriched in the promoters of genes responding to the plant hormones auxin or brassinosteroids (BR) or to both (Nemhauser et al., 2004). Among these elements one had been previously associated with auxin response. However, this element was frequently found in the promoters of brassinosteroid-regulated genes suggesting that it might function as an input sequence for BR signaling as well. Indeed, alterations of BR levels in plants had a strong influence on the activity of an auxin reporter construct containing this element.

In another study, existing information on the binding sites of key regulators of the segmentation gene network of Drosophila was used to computationally predict novel binding sites and modules in the promoters of genes in this network (Schroeder et al., 2004). The functions of these novel modules were tested in vivo and, in general, were found to faithfully drive expression in subdomains of the endogenous genes.

When previous information on cis-regulatory elements is not available, bioinformatics approaches can be used for the identification of over-represented sequence motifs in a group of coexpressed genes that might potentially represent cis-regulatory elements (reviewed in: Li and Wang, 2003, Rombauts et al., 2003). This approach has been successfully used, for example, for the identification of a motif that mediates the circadian control of gene expression in Arabidopsis (Harmer et al., 2000).

Cis-regulatory elements can also be traced by comparing the regulatory regions of orthologous genes of different species. This approach is based on the assumption that important control elements are under selective pressure during evolution and therefore remain relatively unchanged, whereas sequences not required for proper development diversify rapidly. However, as changes in the regulatory regions of orthologous genes are believed to be a source for variation between different species (reviewed in: Wray et al., 2003), the results of such interspecific comparisons can be potentially deceptive (lack of conservation of an element), but, for the same reason, rewarding for obtaining insights into the processes underlying evolution.

Hong et al. have compared the regulatory region of the Arabidopsis floral homeotic gene AGAMOUS with that of the corresponding genes in closely related species of the Brassicaceae family (an approach termed 'phylogenetic shadowing') as well as to distantly related species outside of the Brassicaceae (termed 'phylogenetic footprinting') (Hong et al., 2003). This work led to the identification of novel regulatory elements required for the control of AGAMOUS expression. However, certain previously 
known cis-regulatory elements were not detected by this approach leading the authors to the conclusion that such sequencebased studies should be combined with traditional promoter analysis methods to allow a complete identification of the relevant cis- regulatory elements. Another recently described phylogenetic footprinting approach exploits the extensive duplications in plant genomes. Haberer et al. have suggested that an intragenomic comparison of duplicated genes might allow the identification of cis-regulatory elements (Haberer et al., 2004).

While the identification of cis-regulatory elements is essential for the dissection of a gene network, additional experiments have to be performed to determine the regulatory interactions between the network components. As discussed above, these interactions can be identified by studying the effects that perturbations of single network components have on the other genes in the network. In some cases, these effects can be monitored by comparing the gene expression profile of a wild-type organism to that of a mutant affected in one of the genes in the network. Such a strategy was successfully applied for identifying target genes of the Arabidopsis homeodomain protein BREVIPEDICELLUS (BP) (Mele et al., 2003). By comparing the gene expression of $b p$ mutants to that of wild-type seedlings at a stage before morphological alterations become apparent, several genes involved in lignin biosynthesis were identified. Subsequent analysis revealed that $b p$ mutants have indeed defects in lignin accumulation and that BP can bind to the promoters of some of the identified genes.

Unlike in this example, a disruption of a gene network controlling an important aspect of development leads in many cases to early and such dramatic alterations in the morphology of an organism that a mutant/wild-type comparison will at best produce a list of genes that are expressed in the differentiated organ, tissue, or cell type that might be missing in the mutant. Therefore, different strategies have to be used to study the function of these genes. A particularly useful approach is the specific activation or inactivation of a network component followed by microarray analysis to assess the effects on the expression of other genes in the network. This approach was pioneered by White et al., who have studied the role of the nuclear receptor DHR3 in methamorphosis in Drosophila by prematurely inducing its expression from a heat-shock promoter (White et al., 1999). Gene expression changes were subsequently monitored by microarray analysis, leading to the identification of several putative target genes.

Transcriptional as well as post-translational systems have been described that allow a specific activation of a network component in plants (Lloyd et al., 1994, Zuo and Chua, 2000, Deveaux et al., 2003, Maizel and Weigel, 2004). While transcriptional induction systems are suitable for the activation of any regulatory gene, a post-translational activation is particularly useful for the functional characterization of transcription factors. In this case, use of the translational inhibitor cycloheximide allows the identification of genes that respond to the activation of the factor in the absence of protein synthesis. These genes are good candidates for direct target genes because the synthesis of proteins that might mediate this response is blocked (for example, Sablowski and Meyerowitz, 1998). However, as prolonged treatments with cycloheximide will ultimately lead to cell death, the results of such experiments should be treated with caution.

A better and more direct approach for identifying target genes of a transcription factor on a genome-wide level is to conduct chromatin immunoprecipitation (ChIP) experiments in conjunction with microarray analysis (ChIP/chip). The ChIP/chip method was pioneered in yeast (Reid et al., 2000, Ren et al., 2000, lyer et al., 2001, Lieb et al., 2001) and has already been applied successfully to human cells (Horak et al., 2002b, Li et al., 2003, Martone et al., 2003, Cam et al., 2004, Cawley et al., 2004, Odom et al., 2004). Although such ChIP/chip experiments (to the best of our knowledge) have not yet been reported for the analysis of plant transcription factors, chromatin immunoprecipitation protocols have already been established for an application in plants (see for example: Johnson et al., 2001, Wang et al., 2002, Ramirez-Parra et al., 2004, Turck et al., 2004, Wang et al., 2004b, William et al., 2004) and promoter arrays are being designed (Gao et al., 2004). Thus, this approach will in the near future likely be of great importance for the analysis of gene networks in plant development, as it has been in yeast and mammalian cells (see below).

The specific activation of regulatory genes from a transgene can cause artificial effects on gene expression, for example, due to either over- or mis-expression of the gene. In certain cases it might therefore be preferable to disrupt a network component rather than to activate it. A possible strategy for the targeted inactivation of a gene is the expression of a self-complementary double-stranded RNA from an inducible promoter that results in silencing of a specific gene (inducible RNA interference) (Guo et al., 2003). In addition, it has been demonstrated that transcription factors can be modified so that loss-of-function phenotypes are obtained by fusing transcriptional repressor domains of other factors such as Engrailed from Drosophila or SUPERMAN from Arabidopsis to their coding regions (Markel et al., 2002, Hiratsu et al., 2003) (for a review on the variety of overexpression strategies that are available to study transcription factor functions in plants, see: Zhang, 2003).

A common problem for the application of the experimental approaches described above is the small size of many model organisms. In fact, Arabidopsis was chosen as a model for the study of plant development in part because it is small in size, allowing to keep a large number of plants in the limited space of a laboratory (Meyerowitz, 1989). However, what has been of great benefit for conducting large-scale genetic screens now results in difficulties for the dissection of certain organs, tissues, or cell types for gene expression analysis. Several methods have been developed to overcome these limitations (reviewed in Schnable et al., 2004). For example, laser capture microdissection has been applied to isolate different cell types and tissues of Arabidopsis yielding RNA sufficient in amount and quality for the synthesis of probes for expression profiling experiments (Kerk et al., 2003). Another promising approach is based on the isolation of cells that are marked with green fluorescent protein (GFP) by florescence-activated cell sorting after protoplastation, i.e. enzymatic removal of the cell walls. This technique has been used successfully to profile gene expression in the Arabidopsis root using a variety of cell-type and tissue-specific reporter lines (Birnbaum et al., 2003, see below).

\section{Combining different genome-wide data sources}

The identification of all the elements that may form part of a regulatory network, as complete as it may be, is not sufficient to 
elucidate the network's organization, structure and behavior: the interactions among the different components have to be determined or inferred. For this purpose, it is necessary to combine and/or analyze together different genome-wide datasets, addressing, for example: the identity and location of cis-regulatory elements, their interactions with transcription factors, the identity of the targets of each transcription factor, the patterns of expression of both regulators and targets and even protein-protein interactions. As indicated above, much work has been devoted to the use of genomic sequences to enhance the analysis of gene expression microarray data, through the comparative analyses of promoter sequences of genes with similar expression profiles the underlying assumption being that such genes might be regulated by the same transcription factor(s) or mechanism. A variety of methods and algorithms have been developed over the past few years to identify cis-regulatory elements or motifs in the promoters of co-regulated genes (reviewed in $\mathrm{Li}$ and Wang, 2003). Whereas this approach has been very useful, primarily with relatively small datasets (see examples above), it has a serious shortcoming for tackling large regulatory networks, at least in the way these methods have been usually implemented: they are based on first identifying and grouping the co-regulated genes by clustering analyses, but such analyses do not allow one gene to belong to more than one cluster. This is partly at odds with the combinatorial nature of transcription in eukaryotes: genes sharing the same motif may have different patterns of expression and a given gene, depending on the conditions, may have different transcriptional responses and group with different (or only partially overlapping) sets of genes under each condition. To overcome these limitations, Bussemaker et al. developed a method for the detection of regulatory elements without the need for grouping genes into clusters (the REDUCE algorithm, Bussemaker et al., 2001, Roven and Bussemaker, 2003). This method, which is based on the idea that upstream motifs contribute additively to the log-expression level of a gene, requires a single genome-wide microarray measurement and the promoter sequence of each gene (Bussemaker et al., 2001). Yet an additional limitation in standard clustering methods to guide the discovery of cis-regulatory elements is that all conditions in the dataset are used to measure correlation in expression, whereas in practice, when considering very large datasets, usually only a subset of conditions affect the transcriptional response of a given pathway and thus the consideration of all conditions in the dataset can result in an increase in noise. Therefore, a significant contribution to the field was the development of the 'signature algorithm' by Ihmels et al., which can assign genes to context-dependent and potentially overlapping groups of genes and conditions ('transcription modules') (Ihmels et al., 2002, Ihmels et al., 2004). The 'signature algorithm' was used to analyze over 1,000 gene expression profiles in yeast to characterize genes and conditions associated with cellular pathways, to identify cis-regulatory elements and to analyze the global yeast transcriptional network (Ihmels et al., 2002, Ihmels et al., 2004). The approach should be particularly useful in higher eukaryotes, in which the complexity of the combinatorial code of transcription is higher than in yeast and it has in fact been applied to compare the global transcriptional networks of yeast, E. coli, Arabidopsis, C. elegans, Drosophila and human (Bergmann et al., 2004b).

The combination of gene expression data and cis-regulatory element analyses, even if leading to the identification of transcriptional modules, allows for only an indirect association with the transcription factors that might participate in the regulation of such modules or gene sets. Methods are being developed to associate regulators to transcriptional modules on the basis of expression data alone (for example, Segal et al., 2003), but the most direct link between genes and the transcription factors that regulate them is ultimately obtained by combining gene expression and genome-wide location studies (ChIP/chip). Some of the first ChIP/ chip experiments that were performed in yeast showed that transcription factors may only bind in vivo to a subset of their potential sites (biased recognition) and that they can bind to sequences without recognizable sites (Ren etal., 2000, lyer et al., 2001, Lieb et al., 2001). Importantly, they also showed that transcriptional activators can bind to some of their target promoters even in conditions under which the promoter is not activated (Ren et al., 2000). All these observations highlight the need to combine genome wide location studies with gene expression profiling experiments to determine functional associations. Such combination of global studies has been elegantly used to characterize the yeast cell cycle regulatory network (reviewed in Breeden, 2003): ChIP/chip was performed for the nine known cell cycle transcriptional activators, showing that these factors form themselves a circular network of serial regulation, i.e., factors that are regulators of a given cell cycle stage activate regulators that are involved in the next stage (Simon et al., 2001). Another study encompassed all of the transcription factors that were regulated by one of the cell cycle regulators (SBF), to further characterize the yeast transcriptional circuitry at the G1/S transition (Horak et al., 2002a).

In mammals (and plants, see below), critical regulators of the G1/S transition are the E2F transcription factors, which have also been the target of ChIP/chip experiments (Ren et al., 2002, Weinmann et al., 2002). Those and other studies indicated that, in addition to their well-known role in the G1/S transition, E2Fs also participate in other phases of the cell cycle. More recently, the combination of ChIP/chip and gene expression data has further widened the knowledge on E2F activities (Cam et al., 2004). The mechanism by which E2F proteins control the G1/S transition involves the retinoblastoma (RB) tumor suppressor protein. D-type cyclins are synthesized upon mitogenic stimulation and, through their association with specific CDKs, they trigger the phosphorylation of the RB protein. Non-phosphorylated RB binds to E2F/DP factors, masking their transcriptional activation domain and rendering them inactive. The phosphorylation of RB by the CDK/cyclin complex results in the release of active E2F/DP heterodimers (an E2F protein and a dimerization partner (DP) protein), which are required for the activation of transcription of cell cycle and DNA-synthesis genes and the entry into S phase. In addition, many growth arrest signals in mammals ultimately converge on RB (as well as on the related proteins p130 and p107), such that cells lacking these three proteins fail to arrest in response to serum starvation, contact inhibition, or DNA damaging agents. Cam et al. studied the possible involvement of E2F and $\mathrm{RB}$ family proteins in genome-wide transcriptional regulation of growth arrest (Cam et al., 2004). They identified E2F4 and p130 as the principal E2F and $\mathrm{pRB}$ family members that mediate three different growth arrest pathways. ChIP/chip and gene expression profiling experiments showed that E2F4 and p130 bind to, and 
repress, a common set of genes under each arrest condition, a set that includes not only genes involved in cell cycle control but also in mitochondrial biogenesis and metabolism. Combining their ChIP/chip data with previous data from a different group that analyzed gene expression throughout the cell cycle, they concluded that only approximately one-third of the E2F targets identified in the growth arrest ChIP/chip experiment showed cell cycle periodicity - thus providing further evidence that E2F roles extend beyond the control of the cell cycle. Cam et al. then went further to identify, using a motif finding algorithm to analyze the promoters of E2F-regulated genes, a putative co-regulatory transcription factor, NRF1; performed an additional round of ChIP/ chip experiments with this protein; and finally used small interfering RNAs (siRNAs) to demonstrate that NRF1 is an essential regulator of E2F target genes (Cam et al., 2004). Apart from the biological relevance of the results -a common set of gene regulatory networks linking metabolism and growth inhibition-, the work by Cam et al. elegantly shows the usefulness of combining different genomic techniques and applying them in an iterative manner to unravel gene regulatory networks.

Studies of a larger scale have focused on the global yeast transcriptional network, by individually targeting in ChIP/chip experiments the vast majority of the DNA-binding transcriptional regulators in that organism (Lee et al., 2002, Bar-Joseph et al., 2003, Harbison et al., 2004). Those genome-wide location results were combined with a large number (over 500) of gene expression datasets (Lee etal., 2002, Bar-Joseph etal., 2003), to identify network motifs and groups of genes that are both coordinately bound and coordinately regulated, revealing the high connectivity of the yeast gene regulatory network. Harbison et al. combined genome-wide location data with cis-regulatory element analyses using several yeast species whose genome had been sequenced, to construct an initial map of the regulatory code in yeast by identifying the cis-elements that are bound by regulators under various conditions and that are conserved among Saccharomyces species (Harbison et al., 2004).

The examples mentioned above and many others not cited here, give ample testimony of the recent advances in generating, analyzing and using genomic data to study biological networks. Furthermore, more sophisticated analyses, that involve considering network dynamics or the probabilistic integration of datasets, are underway (Fraser and Marcotte, 2004, Lee et al., 2004, Luscombe et al., 2004). Although studies in plants are at present lagging far behind what is already achievable in yeast, the examples we discuss below demonstrate the great potential that these experimental approaches have for the analysis of the gene networks underlying plant development.

\section{Transcriptional networks in plant development: peek- ing into complexity}

This section summarizes some of the recent advances in our understanding of plant development that have been made possible by the application of genomic technologies. We will focus here only on a few developmental processes, namely flower and root development and the control of the cell cycle. While most genome-wide studies in plants have so far been conducted using Arabidopsis as a model system, the sequencing of additional plant genomes (rice, poplar, alfalfa) and the availability of microarrays for other plant species such as rice, barley, or soybean hold the potential for a more in-depth analysis of plant development by genomic technologies and for cross-species network comparisons within the plant kingdom.

\section{Dissecting LEAFY's role in flower development}

Flowers are formed at the shoot apex after the plant has switched from the vegetative to the reproductive phase of development. Because of the central importance of this transition in the life cycle of a plant, the events that lead up to it and the mechanisms by which it is controlled have been a long-standing interest of plant researchers. Genetic screens have yielded many different mutants with defects in genes controlling the different input pathways that trigger the switch to flowering (Boss et al., 2004, Henderson and Dean, 2004, Jack, 2004, Putterill et al., 2004, Sung and Amasino, 2004). By making use of some of these developmental mutants, Schmid et al. have studied gene expression events at the Arabidopsis shoot apex after a specific induction of flowering and identified genes whose expression is altered during this transition period (Schmid et al., 2003). One of the mutants used in this study, leafy (/fy), is affected in a plantspecific transcription factor that plays a central role for the switch from the vegetative to the reproductive phase (Weigel et al., 1992). LFY is also involved in activating the floral homeotic genes that specify the different types of floral organs (see below). By comparing the gene expression profiles of shoot apices from wildtype plants with that of leafy mutants, Schmid et al. identified genes whose expression changes in an LFY-dependent manner (Fig. 1). Some of these genes were the known LFY targets, namely the floral homeotic genes, a result that proved the applicability and the potential of their method. Among the newly identified LFY-response genes were the three SEPALLATA genes SEP1, SEP2 and SEP3 that function together with the floral homeotic genes in the establishment of floral organ identity (Pelaz et al., 2000, Honma and Goto, 2001, Pelaz et al., 2001a, Pelaz et al., 2001b). The significance of the other identified genes for floral transition or floral patterning (thus, the processes that LFY controls) is currently unknown. Furthermore, it is unclear whether these genes are directly regulated by LFY or whether they are under the control of other LFY-dependent factors.

Additional insights into the function of LFY yielded a study in which gene expression changes were monitored after an ectopic post-translational activation of LFY in seedlings (William et al., 2004) (Fig. 1). Use of the translational inhibitor cycloheximide allowed the identification of putative direct LFY target genes (see above). In total, 15 candidate genes were described that are induced in response to LFY activation in the absence of protein synthesis. Binding of LFY to the promoters of some of these genes was subsequently tested by ChIP analysis, confirming the predictions that were made based on the microarray experiments. In addition, the promoters of these genes were shown to contain the previously described consensus LFY binding site. Thus, the genes identified in this study appear to be bona fide LFY target genes.

Surprisingly, although in the two studies discussed above the same type of whole genome microarray was used no overlap between the predicted target genes was observed (Fig. 1). This could be due to the fact that different types of tissues were used for the experiments: shoot apices in the former and whole seed- 
lings in the latter study. This idea is supported by differences in the detection of known LFY target genes: while in the study by Schmid et al. these genes were readily identified by microarray analysis, they were below the detection threshold in the second study probably due to dilution effects caused by using entire seedlings for the experiments that contain a relatively small number of LFYresponsive cells. Thus, the LFY target genes identified by William et al. are possibly expressed at higher levels than the known targets allowing their detection by microarray analysis. Alternatively, in a worst case scenario, the ectopic activation of LFY may have led to the identification of genes that can be induced by the factor in certain cell-types of a seedling but that are not in the cells where LFY is normally active. Such an effect could be due to a different cellular competence between meristematic and nonmeristematic cells. However, William et al. were able to demonstrate for some of the identified genes that their transcript levels are reduced in Ify mutants compared to wild type and that their expression gradually increase during the switch to flowering when $\angle F Y$ expression increases as well, suggesting that the expression of these genes indeed depends on LFY activity.

While the two studies discussed above provided exciting new information on potential downstream targets of LFY, they also displayed some of the problems and limitations that hamper the application of genomic technologies for the analysis of plant development, especially when the gene of interest is expressed in a spatially and/or temporally limited fashion (see above). An experimental approach that might facilitate the functional analysis of such genes by genomic technologies was described by Wagner et al. who have established a flower induction system that is based on the post-translational activation of LFY in callus (Wagner et al., 2004). In this system, LFY can rapidly activate its known direct target gene APETALA1 in a large portion of the cultured cells leading to a marked enrichment of LFY-responsive cells compared to the seedling approach discussed above. Furthermore, flowers instead of leaves are formed when the callus is transferred to shoot inducing medium indicating that the cultured cells can respond to LFY activity in a way that mimics LFY expressing cells at the shoot apex. Using this system, gene expression changes were monitored in a detailed time course experiment after specific activation of LFY using cDNA microarrays (Fig. 1). Among the approximately 60 LFY-response genes that were identified in this experiment, several genes, including SEP1 and SEP2, had also been described in the two previous studies, demonstrating the suitability of this system for the detection of LFY target genes. Furthermore, in agreement with the proposed role of LFY as a key activator of regulatory genes required for flower formation, a significant enrichment of transcription factors was observed in the data set.

\section{Floral organ identity genes and their targets: towards under- standing morphogenesis}

One of the earliest steps in flower development is the activation of the floral homeotic genes that control the specification of the different types of floral organs. Loss-of-function mutations of these genes lead to homeotic transformations, i.e. the replacement of one type of floral organ by another. Based on the

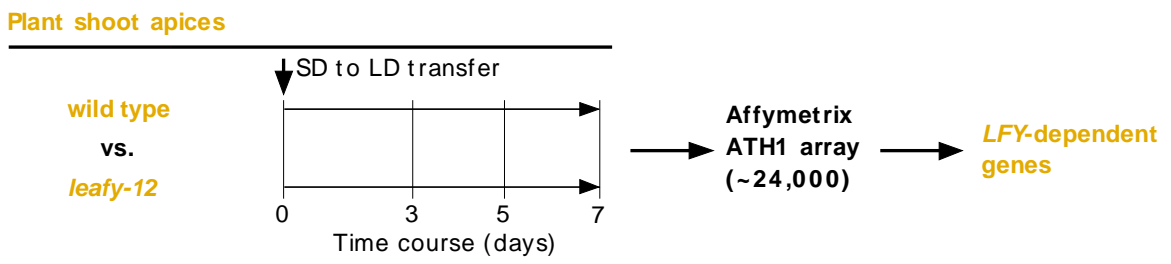

Root explants ( $t$ issue cult ure system)
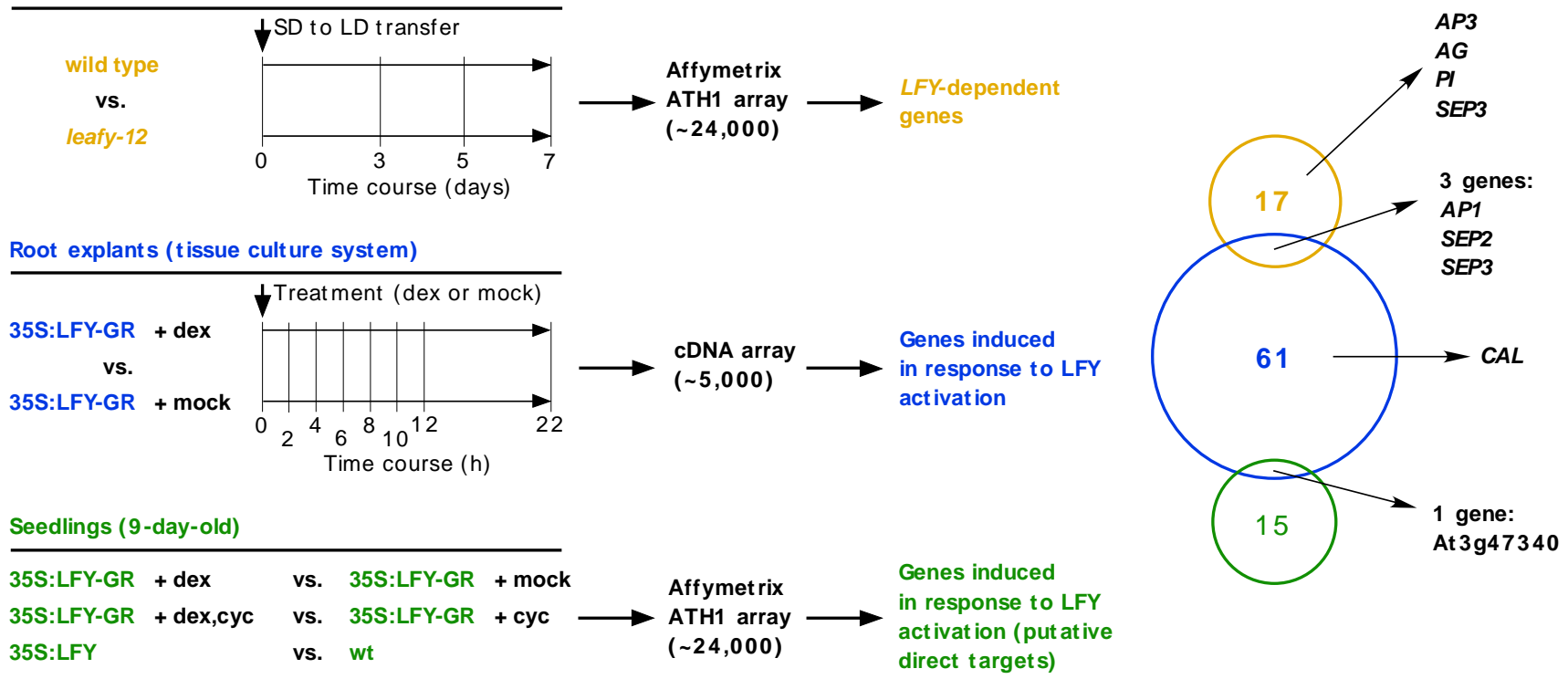

Fig. 1. Identification of $\mathbf{L E A F Y}$-dependent (or target) genes by microarray analyses. Summary of three studies that used different experimental approaches: comparison of wild-type and lfy shoot apices after transferring the plants from a short day (SD) to a long day (LD) light regime (Schmid et al., 2003); time-course gene expression analysis after the posttranslational activation of LFY in root explants (tissue culture system) by using a LFY-GR fusion protein (Wagner et al., 2004); and posttranslational activation of LFY in 9-day-old seedlings (William et al., 2004). The experimental design and the type of microarray used in each case is indicated (the approximate number of Arabidopsis genes that each microarray interrogates is indicated in parenthesis). A comparison of the results obtained is presented in the form of Venn diagrams; numbers inside the diagrams indicate the total number of genes that were identified as differentially expressed in response to (or as dependent on) LFY in each case. GR, glucocorticoid receptor; dex, dexamethasone; cyc, cycloheximide; AP3, APETALA3 ; AG, AGAMOUS ; PI, PISTILLATA ; SEP1-3, SEPALLATA1-3 ; AP1, APETALA1 ; CAL, CAULIFLOWER. 
phenotypes of these mutants the $A B C$ model of floral organ identity determination was proposed. According to this model, the floral homeotic genes can be assigned to one of three different functions $(A, B$, or $C)$ with each function being required in certain regions of the floral meristem. The floral homeotic genes all encode transcription factors and it has been demonstrated that they interact in certain combinations to initiate the developmental programs required for the formation of the different types of floral organs (Lohmann and Weigel, 2002, Jack, 2004). Expression of the floral homeotic genes throughout most of flower development suggests that their role might not be limited to organ initiation. Indeed, an increasing amount of evidence suggests that this prolonged expression is necessary for a full maturation of the floral organs (Bowman et al., 1989, Sablowski and Meyerowitz, 1998, Bey et al., 2004, Ito et al., 2004). Despite of their central function for floral organ formation, information about the target genes of the floral homeotic factors and thus, about the molecular mechanisms by which they control floral organ development is mostly lacking. However, several recent studies have started shedding light on the nature of their target genes by comparing the gene expression profiles of the floral homeotic mutants to that of wild-type plants. In the first of these studies, Zik and Irish have identified target genes of the floral homeotic factors APETALA3 (AP3) and PISTILLATA (PI) that are together required for petal and stamen development in Arabidopsis (Zik and Irish, 2003). They identified $\sim 50$ different transcripts as being under the control of $A P 3 / P I$ and estimated, based on the limited number of genes represented on the CDNA microarray used for their experiments, that the total number of AP3/PI-regulated genes is approximately 200.

In another study, the gene expression profiles of the floral homeotic mutants, including those for $A P 3$ and $P$, were compared to that of wild-type plants using CDNA as well as wholegenome microarrays (Wellmer et al., 2004). By combining the datasets from the individual mutant/wild-type comparisons approximately 1450 transcripts were identified and predicted to be specifically or predominantly expressed in one of the different types of floral organs (Fig. 2). The vast majority of these transcripts were assigned to the reproductive organs, especially to stamens. The expression patterns of some previously uncharacterized genes were subsequently verified by in situ hybridizations and, in general, were found to match the predictions that were made based on the microarray analyses. In addition, genes with known floral organ-specific expression were correctly assigned by this approach.

The total number of genes that depends on AP3/PI activity was estimated in this study to be at least 1200 , a number significantly higher than what had been estimated by Zik and Irish (see above). However, as both studies used whole inflorescences for the microarray experiments it is likely that the transcripts from the relatively small early-stage floral buds were underrepresented in the samples used for gene expression profiling. Thus, many genes regulated by the floral homeotic factors during early flower development were likely missed in these experiments. In addition, it is unclear whether the identified genes are directly regulated by the floral homeotic factors or whether they are merely expressed in the differentiated organs that are missing in the corresponding mutants due to an early disruption of floral organ specification. In any case, these studies provided the first genome-wide informa- tion on gene expression in Arabidopsis flowers that can now severe as a baseline for further, more detailed analyses.

The advantage of using a plant that is larger in size than Arabidopsis for the dissection of developmental processes by gene expression profiling was demonstrated recently by Bey et al., who have studied late petal development in Antirrhinum (Bey et al., 2004). In this study, a temperature-sensitive allele of the $A P 3$-homolog DEFICIENS (DEF) was used to specifically disrupt petal development by shifting mutant plants that were grown at a permissive temperature to a higher, nonpermissive temperature. Subsequently, petal primordia of a certain developmental stage were dissected after 1 or 3 days and their gene expression profiles were compared to that of petal primordia from wild-type plants that were treated identically using macroarrays containing probes for an estimated $\sim 40 \%$ of the transcriptional units of Antirrhinum. About 100 genes were identified whose expression changes in response to the specific inactivation of DEF. The expression of several of these genes was subsequently tested in flowers by in situ hybridizations confirming their dependence on DEF activity.

A different approach for the identification of target genes of a floral homeotic factor was taken by lto et al. who have studied the function of AGAMOUS (AG), which controls the development of the reproductive floral organs in Arabidopsis (Ito et al., 2004). In this study, a posttranslational inducible version of AG was introduced into ag mutant plants and gene expression changes were then monitored in a time course experiment by microarray analysis after a specific activation of $A G$. One of the genes that responded rapidly to an activation of AG was NOZZLE/ SPOROCYTLELESS (NZZ/SPL), a gene that had been previously described as a key regulator of sporogenesis (Schiefthaler et al., 1999, Yang et al., 1999, Balasubramanian and Schneitz, 2000 ), thus a process that occurs relatively late in flower development in the reproductive organs. Interestingly, although AG activation occurred ectopically in the transgenic plants, induction of $N Z Z / S P L$ was only observed in certain floral regions, suggesting that additional regulators are required for this localized expression. To test whether AG may activate $N Z Z / S P L$ directly, the response of $N Z Z / S P L$ to an activation of $A G$ was analyzed in the presence of the translational inhibitor cycloheximide (see above). An inhibition of protein synthesis did not interfere with the induction of the gene, suggesting that the regulation of $N Z Z / S P L$ by $A G$ is direct. Indeed, it was demonstrated that $A G$ binds specifically to an element in the $N Z Z / S P L$ promoter in vitro and that a disruption of this site strongly reduces the expression of the gene in vivo indicating that $N Z Z / S P L$ is a bona fide target gene of $A G$.

\section{Root development}

Root development, as flower development, has been intensively studied by forward genetics leading to the identification of many key regulators and hence, to an emerging knowledge of the gene networks that control the differentiation of the various celltypes found in a root (Birnbaum and Benfey, 2004, Montiel et al., 2004). In order to identify additional components of these networks, Birnbaum et al. analyzed gene expression in the developing root on a genome-wide level (Birnbaum et al., 2003). To this end, they used five different GFP reporter lines marking different cell-types and isolated these cells by fluorescence-activated cell sorting after protoplastation (see above). While this procedure 
resulted in the induction of several hundred genes, control experiments showed that the overall gene expression profiles of the protoplasts were similar to that of cells that were not subjected to protoplastation.

To monitor gene expression in a given cell-type over the course of root development, roots of the five reporter lines were dissected along the apical-based axis to obtain tissue from three different stages of development, thus creating a total of 15 subzones. The gene expression profiles of these subzones were subsequently determined by whole-genome microarray analysis. Clustering of the experimental data led to the identification of groups of genes that are predicted as enriched in one or more subzones. To verify the results of their analysis, Birnbaum et al. analyzed the assignment of genes with known expression in the root and found that the predictions, in general, matched the reported patterns.

In another study, a more specific aspect of root development, namely the formation of lateral roots, was analyzed by gene expression profiling (Himanen et al., 2004). As lateral root initiation in the cells of the pericycle is a relatively rare event and lateral roots do not develop in a synchronized manner, Himanen et al. used a lateral root induction system that allows the simultaneous initiation of a large number of lateral root primordia in Arabidopsis by applying auxin to plants grown in the presence of an auxin transport inhibitor. Gene expression changes that occur in response to the auxin treatment before the first cell divisions take place in the pericycle were monitored in a time course experiment by cDNA microarray analysis. Cluster analysis of the microarray data revealed sets of co-regulated genes that respond to the inductive signal with different kinetics. In these clusters, genes of certain functional categories were found to be under- or overrepresented allowing the definition of stages that precede the formation of lateral root primordia. Many of the early-response genes identified in this experiment are presumably involved in auxin signal transduction. In contrast, the genes that showed a delayed response were enriched for cell-cycle regulators, showing the tight interplay between development and the control of the cell cycle.

\section{The cell cycle network}

Regulation of the cell cycle critically intersects with the regulation of developmental programs, particularly in plants. Plants do not use cell migration or programmed cell death to achieve morphogenesis. Rather, individual cells are the units of plant morphogenesis through their cell division and expansion activities, which are in turn influenced by their cellular neighbors, i.e., coordinated within the organism (Mizukami, 2001, Beemster et al., 2003) (see also review by Crisanto Gutiérrez, this issue). In addition, plant architecture and growth are strongly influenced by environmental conditions. It follows that the control of the cell cycle in plants is intimately linked to developmental processes and that it should also be integrated to external, environmental inputs.

Examples have accumulated that illustrate the interactions between the cell cycle and developmental processes in plants. Many of the transcription factors that have been identified through genetic analyses as playing roles in plant development do so (at least in part) by influencing cellular proliferation, although the molecular connection between them and the cell cycle remains
A

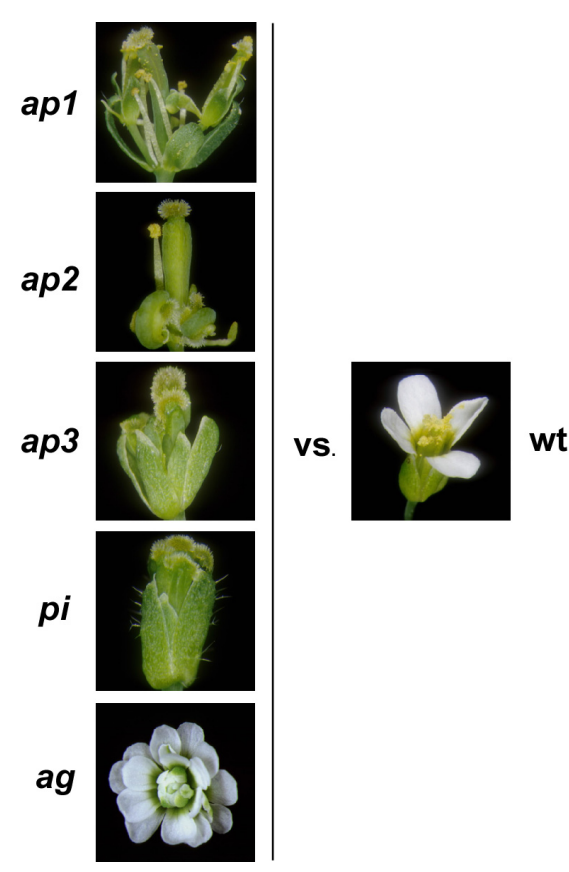

B

Fig. 2. Identification of genes downstream of the floral organ identity regulators by microarray analyses. (A) The gene expression profiles of floral buds from ap1, ap2, ap3, pi and ag mutant plants were compared to that of wild type using cDNA and whole-genome oligonucelotide microarrays (Wellmer et al., 2004). (B) The diagram indicates the expected changes in transcript levels of organ-specific genes in the floral mutants compared with wild-type plants; (-), absent; (upward arrow), upregulated; (downward arrow) downregulated; (?), questionable. The number of genes that were identified as expressed specifically (or predominantly) in each type of organ is indicated. 
largely uncharacterized. For instance, SUPERMAN (SUP) and KNUCKLES (KNU), both $\mathrm{C} 2 \mathrm{H} 2$ zinc finger transcription factors, are negative regulators of cellular proliferation, SUP controlling floral patterning (maintenance of the boundary between the stamen and carpel whorls) and ovule development (Nandi et al., 2000, Sakai etal., 2000) and KNU regulating gynoecium development and floral determinacy (Payne et al., 2004). Conversely, JAGGED (JAG) and RABBIT EARS (RBE), also C2H2 proteins, induce cell proliferation (Dinneny et al., 2004, Ohno et al., 2004, Takeda et al., 2004). PETAL LOSS (PTL), a trihelix transcription factor, regulates perianth architecture by suppressing growth between initiating sepals (Brewer et al., 2004). The Antirrhinum TCP transcription factors CYCLOIDEA and CINCINNATA control growth in leaves and petals (Cubas et al., 1999, Nath et al., 2003, Crawford et al., 2004). Other examples include CUC1 and CUC2 and AINTEGUMENTA (ANT), from the NAC and AP2/ERF families of transcription factors, respectively, and homeobox genes. More directly, a cyclin-dependent kinase (Arabidopsis CDKE, a homolog of human CDK8) was recently shown to be necessary for the specification of reproductive organ (i.e., stamen and carpel) identity and for the proper termination of stem cells in the floral meristem, illustrating how cell cycle components can play a role in cellular differentiation processes (Wang and Chen, 2004).

As illustrated earlier, the cell cycle regulatory network and the transcription factors that form part of it, have been a model to prototype multiple genomic methods and concepts, particularly in yeast. In that organism, it was one of the first networks for which what we might call a genome-wide view was obtained. What can we learn from those studies, in yeast and mammals, that can help us elucidate the cell cycle regulatory network in plants? How similar might the plant network be to those from other organisms and kingdoms? What have we learned so far about the plant cell cycle using genomic tools?

As in other eukaryotes, the cell cycle in plants is driven by CDKcontrolled phosphorylation at the G1/S and G2/M transitions (for a review, De Veylder et al., 2003). Substantial parts of the cell cycle machinery are, as expected, conserved across eukaryotes: CDKs, cyclins, CDK inhibitors and the WEE1 kinase are all present in the plant lineage (Vandepoele et al., 2002, Robbens et al., 2005). However, plants show some particular features, such as several plant-specific CDKs and cyclins and an overall higher number of cyclin genes (Vandepoele et al., 2002, Wang et al., 2004a).

Downstream of the CDK/cyclin pathways, regulation of the cell cycle transitions and the progression through it is largely dependent on transcriptional control, through the activation (and repression) of the cohorts of genes that are required at the distinct cell cycle phases. The transcriptional network that regulates the cell cycle in plants is less well understood than in the case of $\mathcal{S}$. cerevisiae or of mammalian cells. However, homologs to some of the known mammalian cell cycle transcriptional regulators can be identified in plants. Moreover, evidence is accumulating, especially in Arabidopsis, that such regulators may be organized in regulatory pathways equivalent to those of animal cells, although plant-specific innovations are also apparent. It is still unclear, though, whether in plants these regulators are connected through a cascade cycle of serial activation, as in $S$. cerevisiae (Simon et al., 2001, see above, Horak et al., 2002a, Breeden, 2003).

The mechanism that regulates the G1/S transition, which involves E2F and RB proteins (see above), appears to be conserved between mammals and plants (De Veylder et al., 2003). The Arabidopsis genome contains eight genes belonging to the E2F/DP family and a single gene for an RB-related protein (RBR), in addition to D-type cyclins and A-type CDKs. It has been shown that tobacco RBR protein is phosphorylated by a CDKA/cyclinD complex in a cell-cycle-dependent manner, peaking at the G1/S transition point (Nakagami et al., 2002). Furthermore, overexpression of a D-type cyclin (CYCD3;1) in Arabidopsis pushes cells from G1 into S (Dewitte et al., 2003). In summary, all the necessary components of the E2F-RB pathway are present in plants, as they are in animals.

The Arabidopsis E2F/DP family consists of three AtE2F genes (known as AtE2Fa/AtE2F3, AtE2Fb/AtE2F1 and AtE2Fc/AtE2F2), two DP genes and three E2F-like genes (known as DELs, E2Ls, or E2Fd-f) (Gutierrez et al., 2002, Shen, 2002). AtE2Fa could, like mammalian E2F1, E2F2 and E2F3, be a direct and specific activator of S-phase genes (De Veylder et al., 2002, Rossignol et al., 2002). AtE2Fc, on the other hand, might function as a negative regulator of cell division, resembling mammalian E2F6 (del Pozo et al., 2002, Stevens and La Thangue, 2003). Another negative input in the E2F network may be repression carried out by the DEL proteins, which can bind to DNA in a monomeric form and repress the expression of genes under E2F control (Kosugi and Ohashi, 2002). DEL or E2F-like proteins were first identified in Arabidopsis ; a similar E2F-like protein has been recently identified in mammals (named E2F7) and it has been shown that it can repress E2F target genes and cause the accumulation of cells in G1 (Kosugi and Ohashi, 2002, de Bruin et al., 2003, Di Stefano et al., 2003). In summary, although we are still far from understanding the specific functions or roles of the individual plant E2F/DP family members, it appears that they are likely organized in a network that, like the E2F network of mammals, relies on a balance of negative and positive inputs.

The regulation of the G2/M transition in plants is less well understood than the pathways that direct entry into $S$ phase. There is some, albeit incomplete, information about the transcriptional regulators and events that might operate downstream of the G2/M CDK-cyclin module in plants. Plant B-type cyclins show a peak of transcription at the late $\mathrm{G} 2$ and $M$ phases during the cell cycle. The promoters of B-type cyclin genes contain a motif that directs $\mathrm{G} 2 / \mathrm{M}$ specific gene expression, called the MSA element (Ito et al., 2001). In tobacco, it has been shown that the MSA element is specifically recognized by MYB proteins of the threerepeat type (MYB-R1R2R3), that is, they are analogous to the animal c-MYB proteins (Ito et al., 2001). It has been proposed that G2/M-phase-specific gene expression is mediated by these Ntmyb proteins, with the balance between activators (NtmybA1 and $\mathrm{NtmybA2}$ ) and repressor (NtmybB) ensuring that no inappropriate triggering occurs (Ito et al., 2001, Araki et al., 2004). However, because NtmybA1 and NtmybA2 are themselves cell cycle regulated in a similar manner to, but preceding, their target, it is still unclear how much of a G2/M trigger role (versus a reinforcing one) they actually play. Initial microarray experiments to characterize gene expression during the Arabidopsis cell cycle (Menges et al., 2002 , see below) have identified genes ( 100) with similar kinetics of expression to those of the cyclin B genes, but only about $20 \%$ of those contain an MSA element in their promoter. In mammals, all their three myb proteins, $c-M y b, A-M y b$ and B-Myb, 
play an important role in regulating the cell cycle, but they act specifically at the G1/S transition (Weston, 1998). Thus, although Myb proteins of the three-repeat type form part of the cell cycle network in plants, they play a different role in it than their mammalian counterparts.

Little is known about the genes that are regulated by the different E2F proteins in Arabidopsis, but recent results point to the conservation, at least partial, of the E2F transcriptional cascade between plants and animals (Ramirez-Parra et al., 2003). Thus a search for putative E2F binding sites in the Arabidopsis genome led to the identification of over 180 potential E2F targets and cell-cycle regulated expression was confirmed for several of those genes by RT-PCR (Ramirez-Parra et al., 2003). Human homologs could be identified for at least a fraction of the Arabidopsis putative E2F targets. These human genes included previously identified E2F-regulated genes, as well as novel genes with E2F binding sites in their promoters (Ramirez-Parra et al., 2003). In another study, the transcript profile of transgenic Arabidopsis lines that overexpress E2Fa-DPa has been compared to that of wild-type plants using a small microarray (Vlieghe et al., 2003). This experiment identified some putative direct and indirect E2F targets. Among the genes supposed to be primary targets were genes involved in DNA-synthesis, whereas among the putative indirect targets genes linked to nitrogen assimilation were found, suggesting a cross-talking genetic network between DNA replication and nitrogen metabolism. In summary, the scope of transcriptional regulation exerted by the E2F proteins in plants remains largely unexplored, although preliminary data support some of the presumed roles for these proteins in controlling the G1/S transition and point to similarities, at the network level, with mammals. No similar studies have been reported yet for the MYB-R1R2R3 proteins that might regulate the G2/M transition.

The comprehensive characterization of cell-cycle regulated gene expression in Arabidopsis, using synchronized cell populations and with high temporal resolution, is a necessary dataset for the elucidation of the regulatory network. Preliminary analyses of this type have been recently reported, using Affymetrix Arabidopsis chips (Menges et al., 2002, Menges et al., 2003). These experiments resulted in the identification of $\sim 1,000$ genes that display cell-cycle-regulated or -associated expression. However, none of the known or presumed cell cycle transcriptional regulator of Arabidopsis (the E2F, DP, DEL and MYB genes described above) are present in that list of genes, despite the fact that, for at least some of them, cell-cycle related expression patterns have been described by other methods (usually, PCR-based). Whether this failure to detect the known regulators results from limitations of the microarray technology (in particular, sensitivity) or from the way the data sets were filtered and analyzed is unclear.

In summary, cell cycle research in plants has relied heavily on the knowledge gained with other species. In part based on that, the basic building blocks of the plant cell cycle regulatory network are being put together. Genomic technologies are being used, but we are still far from being able to assemble the data into a coherent, functional network, not the least because of the absence of important types of data, such as ChIP/chip. In particular, it is not known whether a continuous cycle of interdependent waves of transcription will also be found in the plant cell cycle, akin to what has been observed in S. cerevisiae (Simon et al., 2001, Horak etal., 2002a, Breeden, 2003) - but, somewhat surprisingly, not in S. pombe (Rustici et al., 2004). Evidence of connections between the different cell cycle transitions or checkpoints in plants, however, is starting to accumulate (see, for example, Boudolf et al., 2004). Lastly, the molecular connection between the regulation of the cell cycle and those regulators of development that influence it is still uncharacterized.

\section{Conclusion}

The results of the studies we have discussed above show the great potential that the use of genomic technologies has for the analysis of the gene regulatory networks underlying development. However, they also demonstrate that the implementation of novel or improved experimental approaches will be necessary to redeem the promise of a truly genome-wide understanding of development. This is especially true for the study of plant development, for which the application of genomic technologies is currently almost entirely limited to gene expression profiling by microarray analysis. While gene expression profiling has proven to be an invaluable tool for identifying probable components of the gene networks that control specific developmental processes, it cannot yield a comprehensive understanding of the hierarchical relationships within a gene network. Thus, future studies will have to focus on the genome-wide analysis of cis-regulatory interactions in plants by making use of some of the experimental approaches discussed above, such as phylogenetic footprinting or ChIP/chip analysis.

\section{Acknowledgments}

We are grateful to our colleagues at Caltech and especially to members of Prof. Elliot Meyerowitz's laboratory for their interest and work in gene regulatory networks. Our work on flower development using genomic technologies, described in this review, was supported by grants from the National Institutes of Health (grant GM45697) and the US Department of Energy (grant FG03-88ER13873) to Elliot Meyerowitz and by the Millard and Muriel Jacobs Genetics and Genomics Laboratory at Caltech, which José Luis Riechmann directs. Frank Wellmer was partially supported by an Emmy Noether fellowship of the Deutsche Forschungsgemeinschaft.

\section{References}

ARAKI, S., ITO, M., SOYANO, T., NISHIHAMA, R. and MACHIDA, Y. (2004). Mitotic cyclins stimulate the activity of c-Myb-like factors for transactivation of G2/M phase-specific genes in tobacco. J. Biol. Chem. 279: 32979-32988.

ARBEITMAN, M.N., FURLONG, E.E., IMAM, F., JOHNSON, E., NULL, B.H., BAKER, B.S., KRASNOW, M.A., SCOTT, M.P., DAVIS, R.W. and WHITE, K.P. (2002). Gene expression during the life cycle of Drosophila melanogaster. Science 297: 2270-5.

BALASUBRAMANIAN, S. and SCHNEITZ, K. (2000). NOZZLE regulates proximaldistal pattern formation, cell proliferation and early sporogenesis during ovule development in Arabidopsis thaliana. Development 127: 4227-38.

BAR-JOSEPH, Z., GERBER, G.K., LEE, T.I., RINALDI, N.J., YOO, J.Y., ROBERT, F., GORDON, D.B., FRAENKEL, E., JAAKKOLA, T.S., YOUNG, R.A. et al. (2003). Computational discovery of gene modules and regulatory networks. Nature Biotechnol. 21: 1337-42.

BAUGH, L.R., HILL, A.A., SLONIM, D.K., BROWN, E.L. and HUNTER, C.P. (2003). Composition and dynamics of the Caenorhabditis elegans early embryonic transcriptome. Development 130: 889-900.

BEEMSTER, G.T., FIORANI, F. and INZE, D. (2003). Cell cycle: the key to plant growth control? Trends Plant Sci. 8: 154-8.

BERGMANN, D.C., LUKOWITZ, W. and SOMERVILLE, C.R. (2004a). Stomatal 
development and pattern controlled by a MAPKK kinase. Science 304: 14947.

BERGMANN, S., IHMELS, J. and BARKAI, N. (2004b). Similarities and differences in genome-wide expression data of six organisms. PLOS Biol. 2: E9

BERTONE, P., STOLC, V., ROYCE, T.E., ROZOWSKY, J.S., URBAN, A.E., ZHU, X., RINN, J.L., TONGPRASIT, W., SAMANTA, M., WEISSMAN, S. et al. (2004). Global identification of human transcribed sequences with genome tiling arrays. Science 306: 2242-6.

BEY, M., STUBER, K., FELLENBERG, K., SCHWARZ-SOMMER, Z., SOMMER, $H$., SAEDLER, $H$. and ZACHGO, S. (2004). Characterization of Antirrhinum petal development and identification of target genes of the class B MADS box gene DEFICIENS. Plant Cel/ 16: 3197-215.

BIRNBAUM, K. and BENFEY, P.N. (2004). Network building: transcriptional circuits in the root. Curr. Opin. Plant. Biol. 7: 582-8.

BIRNBAUM, K., SHASHA, D.E., WANG, J.Y., JUNG, J.W., LAMBERT, G.M., GALBRAITH, D.W. and BENFEY, P.N. (2003). A gene expression map of the Arabidopsis root. Science 302: 1956-60.

BOSS, P.K., BASTOW, R.M., MYLNE, J.S. and DEAN, C. (2004). Multiple pathways in the decision to flower: enabling, promoting and resetting. Plant Cel/ 16 Suppl: S18-31.

BOUDOLF, V., VLIEGHE, K., BEEMSTER, G.T., MAGYAR, Z., ACOSTA, J.A., MAES, S., VAN DER SCHUEREN, E., INZE, D. and DE VEYLDER, L. (2004). The plant-specific cyclin-dependent kinase CDKB1;1 and transcription factor E2Fa-DPa control the balance of mitotically dividing and endoreduplicating cells in Arabidopsis. Plant Cell 16: 2683-2692.

BOWMAN, J.L., ESHED, Y. and BAUM, S.F. (2002). Establishment of polarity in angiosperm lateral organs. Trends Genet. 18: 134-41.

BOWMAN, J.L., SMYTH, D.R. and MEYEROWITZ, E.M. (1989). Genes directing flower development in Arabidopsis. Plant Cel/ 1: 37-52.

BREEDEN, L.L. (2003). Periodic transcription: a cycle within a cycle. Curr. Biol. 13: R31-8.

BREWER, P.B., HOWLES, P.A., DORIAN, K., GRIFFITH, M.E., ISHIDA, T., KAPLAN-LEVY, R.N., KILINC, A. and SMYTH, D.R. (2004). PETAL LOSS, a trihelix transcription factor gene, regulates perianth architecture in the Arabidopsis flower. Development 131: 4035-45.

BUSSEMAKER, H.J., LI, H. and SIGGIA, E.D. (2001). Regulatory element detection using correlation with expression. Nature Genet. 27: 167-71.

CAM, H., BALCIUNAITE, E., BLAIS, A., SPEKTOR, A., SCARPULLA, R.C., YOUNG, R., KLUGER, Y. and DYNLACHT, B.D. (2004). A common set of gene regulatory networks links metabolism and growth inhibition. Mol. Cel/ 16: 399411.

CAWLEY, S., BEKIRANOV, S., NG, H.H., KAPRANOV, P., SEKINGER, E.A., KAMPA, D., PICCOLBONI, A., SEMENTCHENKO, V., CHENG, J., WILLIAMS, A.J. et al. (2004). Unbiased mapping of transcription factor binding sites along human chromosomes 21 and 22 points to widespread regulation of noncoding RNAs. Cel/ 116: 499-509.

CRAWFORD, B.C., NATH, U., CARPENTER, R. and COEN, E.S. (2004). CINCINNATA controls both cell differentiation and growth in petal lobes and leaves of Antirrhinum. Plant Physiol. 135: 244-53.

CUBAS, P., LAUTER, N., DOEBLEY, J. and COEN, E. (1999). The TCP domain: a motif found in proteins regulating plant growth and development. Plant J. 18: 215-22.

DAVIDSON, E.H. (2001). Genomic regulatory systems: Development and evolution. Academic Press, San Diego.

DAVIDSON, E.H., RAST, J.P., OLIVERI, P., RANSICK, A., CALESTANI, C., YUH, C.H., MINOKAWA, T., AMORE, G., HINMAN, V., ARENAS-MENA, C. et al. (2002). A genomic regulatory network for development. Science 295: 1669-78.

DE BRUIN, A., MAITI, B., JAKOI, L., TIMMERS, C., BUERKI, R. and LEONE, G. (2003). Identification and characterization of E2F7, a novel mammalian E2F family member capable of blocking cellular proliferation. J. Biol. Chem. 278: 42041-9.

DE VEYLDER, L., BEECKMAN, T., BEEMSTER, G.T., DE ALMEIDA ENGLER, J., ORMENESE, S., MAES, S., NAUDTS, M., VAN DER SCHUEREN, E. JACQMARD, A., ENGLER, G. et al. (2002). Control of proliferation, endoreduplication and differentiation by the Arabidopsis E2Fa-DPa transcription factor. EMBO J. 21: 1360-8.
DE VEYLDER, L., JOUBES, J. and INZE, D. (2003). Plant cell cycle transitions. Curr. Opin. Plant. Biol. 6: 536-43.

DEL POZO, J.C., BONIOTTI, M.B. and GUTIERREZ, C. (2002). Arabidopsis E2Fc functions in cell division and is degraded by the ubiquitin-SCF(AtSKP2) pathway in response to light. Plant Cel/ 14: 3057-71.

DEVEAUX, Y., PEAUCELLE, A., ROBERTS, G.R., COEN, E., SIMON, R., MIZUKAMI, Y., TRAAS, J., MURRAY, J.A., DOONAN, J.H. and LAUFS, P. (2003). The ethanol switch: a tool for tissue-specific gene induction during plant development. Plant J. 36: 918-30.

DEWITTE, W., RIOU-KHAMLICHI, C., SCOFIELD, S., HEALY, J.M., JACQMARD, A., KILBY, N.J. and MURRAY, J.A. (2003). Altered cell cycle distribution, hyperplasia and inhibited differentiation in Arabidopsis caused by the D-type cyclin CYCD3. Plant Cell 15: 79-92.

DISTEFANO, L., JENSEN, M.R. and HELIN, K. (2003). E2F7, a novel E2F featuring $D P$-independent repression of a subset of E2F-regulated genes. EMBO J. 22: 6289-98

DINNENY, J.R., YADEGARI, R., FISCHER, R.L., YANOFSKY, M.F. and WEIGEL, D. (2004). The role of JAGGED in shaping lateral organs. Development 131 1101-10.

ENGSTROM, E.M., IZHAKI, A. and BOWMAN, J.L. (2004). Promoter bashing, microRNAs and knox Genes. New insights, regulators and targets-of-regulation in the establishment of lateral organ polarity in Arabidopsis. Plant Physiol. 135 685-94.

ESPINOSA-SOTO, C., PADILLA-LONGORIA, P. and ALVAREZ-BUYLLA, E.R. (2004). A gene regulatory network model for cell-fate determination during Arabidopsis thaliana flower development that is robust and recovers experimental gene expression profiles. Plant Cell 16: 2923-39.

FRASER, A.G. and MARCOTTE, E.M. (2004). A probabilistic view of gene function. Nature Genet. 36: 559-64

FURLONG, E.E. andERSEN, E.C., NULL, B., WHITE, K.P. and SCOTT, M.P. (2001). Patterns of gene expression during Drosophila mesoderm development. Science 293: 1629-33

GAO, Y., LI, J., STRICKLAND, E., HUA, S., ZHAO, H., CHEN, Z., QU, L. and DENG, X.W. (2004). An Arabidopsis promoter microarray and its initial usage in the identification of HY5 binding targets in vitro. Plant Mol. Biol. 54: 683-99.

GRUNENFELDER, B. and WINZELER, E.A. (2002). Treasures and traps in genome-wide data sets: case examples from yeast. Nat. Rev. Genet. 3: 653-61.

GUO, H.S., FEI, J.F., XIE, Q. and CHUA, N.H. (2003). A chemical-regulated inducible RNAi system in plants. Plant J. 34: 383-92.

GUTIERREZ, C., RAMIREZ-PARRA, E., CASTELLANO, M.M. and DEL POZO, J.C. (2002). $\mathrm{G}(1)$ to $S$ transition: more than a cell cycle engine switch. Curr Opin. Plant. Biol. 5: 480-6.

HABERER, G., HINDEMITT, T., MEYERS, B.C. and MAYER, K.F. (2004). Transcriptional similarities, dissimilarities and conservation of cis-elements in duplicated genes of Arabidopsis. Plant Physiol. 136: 3009-22.

HARBISON, C.T., GORDON, D.B., LEE, T.I., RINALDI, N.J., MACISAAC, K.D. DANFORD, T.W., HANNETT, N.M., TAGNE, J.B., REYNOLDS, D.B., YOO, J. et al. (2004). Transcriptional regulatory code of a eukaryotic genome. Nature 431: $99-104$

HARMER, S.L., HOGENESCH, J.B., STRAUME, M., CHANG, H.S., HAN, B., ZHU, T., WANG, X., KREPS, J.A. and KAY, S.A. (2000). Orchestrated transcription of key pathways in Arabidopsis by the circadian clock. Science 290: 2110-3.

HENDERSON, I.R. and DEAN, C. (2004). Control of Arabidopsis flowering: the chill before the bloom. Development 131: 3829-38.

HILL, A.A., HUNTER, C.P., TSUNG, B.T., TUCKER-KELLOGG, G. and BROWN, E.L. (2000). Genomic analysis of gene expression in C. elegans. Science 290: 809-12.

HIMANEN, K., VUYLSTEKE, M., VANNESTE, S., VERCRUYSSE, S., BOUCHERON, E., ALARD, P., CHRIQUI, D., VAN MONTAGU, M., INZE, D. and BEECKMAN, T. (2004). Transcript profiling of early lateral root initiation. Proc. Natl. Acad. Sci. USA 101: 5146-51.

HIRATSU, K., MATSUI, K., KOYAMA, T. and OHME-TAKAGI, M. (2003). Dominant repression of target genes by chimeric repressors that include the EAR motif, a repression domain, in Arabidopsis. Plant J. 34: 733-9.

HONG, R.L., HAMAGUCHI, L., BUSCH, M.A. and WEIGEL, D. (2003). Regulatory elements of the floral homeotic gene AGAMOUS identified by phylogenetic 
footprinting and shadowing. Plant Cel/ 15: 1296-1309.

HONMA, T. and GOTO, K. (2001). Complexes of MADS-box proteins are sufficient to convert leaves into floral organs. Nature 409: 525-9.

HORAK, C.E., LUSCOMBE, N.M., QIAN, J., BERTONE, P., PICCIRRILLO, S., GERSTEIN, M. and SNYDER, M. (2002a). Complex transcriptional circuitry at the G1/S transition in Saccharomyces cerevisiae. Genes Dev. 16: 3017-33.

HORAK, C.E., MAHAJAN, M.C., LUSCOMBE, N.M., GERSTEIN, M., WEISSMAN, S.M. and SNYDER, M. (2002b). GATA-1 binding sites mapped in the betaglobin locus by using mammalian chlp-chip analysis. Proc. Natl. Acad. Sci. USA 99: 2924-9.

IDEKER, T. (2004). A systems approach to discovering signaling and regulatory pathways-or, how to digest large interaction networks into relevant pieces. Adv. Exp. Med. Biol. 547: 21-30.

IDEKER, T., THORSSON, V., RANISH, J.A., CHRISTMAS, R., BUHLER, J., ENG, J.K., BUMGARNER, R., GOODLETT, D.R., AEBERSOLD, R. and HOOD, L. (2001). Integrated genomic and proteomic analyses of a systematically perturbed metabolic network. Science 292: 929-34.

IHMELS, J., BERGMANN, S. and BARKAI, N. (2004). Defining transcription modules using large-scale gene expression data. Bioinformatics 20: 19932003.

IHMELS, J., FRIEDLANDER, G., BERGMANN, S., SARIG, O., ZIV, Y. and BARKAI, N. (2002). Revealing modular organization in the yeast transcriptional network. Nature Genet. 31: 370-7.

ITO, M., ARAKI, S., MATSUNAGA, S., ITOH, T., NISHIHAMA, R., MACHIDA, Y., DOONAN, J.H. and WATANABE, A. (2001). G2/M-phase-specific transcription during the plant cell cycle is mediated by c-Myb-like transcription factors. Plant Cell 13: 1891-905.

ITO, T., WELlmeR, F., YU, H., DAS, P., ITO, N., ALVES-FERREIRA, M., RIECHMANN, J.L. and MEYEROWITZ, E.M. (2004). The homeotic protein AGAMOUS controls microsporogenesis by regulation of SPOROCYTELESS. Nature 430: 356-60.

IYER, V.R., HORAK, C.E., SCAFE, C.S., BOTSTEIN, D., SNYDER, M. and BROWN, P.O. (2001). Genomic binding sites of the yeast cell-cycle transcription factors SBF and MBF. Nature 409: 533-8.

JACK, T. (2004). Molecular and genetic mechanisms of floral control. Plant Cel/ 16 Suppl: S1-17.

JIANG, M., RYU, J., KIRALY, M., DUKE, K., REINKE, V. and KIM, S.K. (2001). Genome-wide analysis of developmental and sex-regulated gene expression profiles in Caenorhabditis elegans. Proc. Natl. Acad. Sci. USA 98: 218-23.

JOHNSON, C., BODEN, E., DESAI, M., PASCUZZI, P. and ARIAS, J. (2001). In vivo target promoter-binding activities of a xenobiotic stress-activated TGA factor. Plant J. 28: 237-43.

KAMPA, D., CHENG, J., KAPRANOV, P., YAMANAKA, M., BRUBAKER, S., CAWLEY, S., DRENKOW, J., PICCOLBONI, A., BEKIRANOV, S., HELT, G. et al. (2004). Novel RNAs identified from an in-depth analysis of the transcriptome of human chromosomes 21 and 22. Genome Res. 14: 331-42.

KAPRANOV, P., CAWLEY, S.E., DRENKOW, J., BEKIRANOV, S., STRAUSBERG, R.L., FODOR, S.P. and GINGERAS, T.R. (2002). Large-scale transcriptional activity in chromosomes 21 and 22. Science 296: 916-9.

KERK, N.M., CESERANI, T., TAUSTA, S.L., SUSSEX, I.M. and NELSON, T.M. (2003). Laser capture microdissection of cells from plant tissues. Plant Physiol. 132: $27-35$

KOSUGI, S. and OHASHI, Y. (2002). E2Ls, E2F-like repressors of Arabidopsis that bind to E2F sites in a monomeric form. J. Biol. Chem. 277: 16553-8.

LEE, I., DATE, S.V., ADAI, A.T. and MARCOTTE, E.M. (2004). A probabilistic functional network of yeast genes. Science 306: 1555-8.

LEE, T.I., RINALDI, N.J., ROBERT, F., ODOM, D.T., BAR-JOSEPH, Z., GERBER, G.K., HANNETT, N.M., HARBISON, C.T., THOMPSON, C.M., SIMON, I. et al. (2002). Transcriptional regulatory networks in Saccharomyces cerevisiae. Science 298: 799-804.

LESCOT, M., DEHAIS, P., THIJS, G., MARCHAL, K., MOREAU, Y., VAN DE PEER, Y., ROUZE, P. and ROMBAUTS, S. (2002). PlantCARE, a database of plant cisacting regulatory elements and a portal to tools for in silico analysis of promoter sequences. Nucleic Acids Res. 30: 325-7.

$\mathrm{LI}, \mathrm{H}$. and WANG, W. (2003). Dissecting the transcription networks of a cell using computational genomics. Curr. Opin. Genet. Dev. 13: 611-6.
LI, Z., VAN CALCAR, S., QU, C., CAVENEE, W.K., ZHANG, M.Q. and REN, B. (2003). A global transcriptional regulatory role for c-Myc in Burkitt's lymphoma cells. Proc. Natl. Acad. Sci. USA 100: 8164-9

LIEB, J.D., LIU, X., BOTSTEIN, D. and BROWN, P.O. (2001). Promoter-specific binding of Rap1 revealed by genome-wide maps of protein-DNA association. Nature Genet. 28: 327-34

LLOYD, A.M., SCHENA, M., WALBOT, V. and DAVIS, R.W. (1994). Epidermal cell fate determination in Arabidopsis: patterns defined by a steroid-inducible regulator. Science 266: 436-439.

LOHMANN, J.U. and WEIGEL, D. (2002). Building beauty: the genetic control of floral patterning. Dev. Cell 2: 135-42.

LUKOWITZ, W., ROEDER, A., PARMENTER, D. and SOMERVILLE, C. (2004). A MAPKK kinase gene regulates extra-embryonic cell fate in Arabidopsis. Cell 116: 109-19.

LUSCOMBE, N.M., BABU, M.M., YU, H., SNYDER, M., TEICHMANN, S.A. and GERSTEIN, M. (2004). Genomic analysis of regulatory network dynamics reveals large topological changes. Nature 431: 308-12.

MAIZEL, A. and WEIGEL, D. (2004). Temporally and spatially controlled induction of gene expression in Arabidopsis thaliana. Plant J. 38: 164-71.

MARKEL, H., CHANDLER, J. and WERR, W. (2002). Translational fusions with the engrailed repressor domain efficiently convert plant transcription factors into dominant-negative functions. Nucleic Acids Res. 30: 4709-19.

MARTONE, R., EUSKIRCHEN, G., BERTONE, P., HARTMAN, S., ROYCE, T.E., LUSCOMBE, N.M., RINN, J.L., NELSON, F.K., MILLER, P., GERSTEIN, M. et al. (2003). Distribution of NF-\{kappa\}B-binding sites across human chromosome 22. Proc. Natl. Acad. Sci. USA 100: 12247-12252.

MELE, G., ORI, N., SATO, Y. and HAKE, S. (2003). The knotted1-like homeobox gene BREVIPEDICELLUS regulates cell differentiation by modulating metabolic pathways. Genes Dev. 17: 2088-2093.

MENGES, M., HENNIG, L., GRUISSEM, W. and MURRAY, J.A. (2002). Cell cycleregulated gene expression in Arabidopsis. J. Biol. Chem. 277: 41987-2002.

MENGES, M., HENNIG, L., GRUISSEM, W. and MURRAY, J.A. (2003). Genomewide gene expression in an Arabidopsis cell suspension. Plant Mol. Biol. 53: 423-42.

MEYEROWITZ, E.M. (1989). Arabidopsis, a useful weed. Cel/ 56: 263-9.

MIZUKAMI, Y. (2001). A matter of size: developmental control of organ size in plants. Curr. Opin. Plant. Biol. 4: 533-9.

MONTIEL, G., GANTET, P., JAY-ALLEMAND, C. and BRETON, C. (2004). Transcription factor networks. Pathways to the knowledge of root development. Plant Physiol. 136: 3478-85.

NAKAGAMI, H., KAWAMURA, K., SUGISAKA, K., SEKINE, M. and SHINMYO, A. (2002). Phosphorylation of retinoblastoma-related protein by the cyclin D/ cyclin-dependent kinase complex is activated at the G1/S-phase transition in tobacco. Plant Cell 14: 1847-57.

NANDI, A.K., KUSHALAPPA, K., PRASAD, K. and VIJAYRAGHAVAN, U. (2000) A conserved function for Arabidopsis SUPERMAN in regulating floral-whorl cell proliferation in rice, a monocotyledonous plant. Curr. Biol. 10: 215-8.

NATH, U., CRAWFORD, B.C., CARPENTER, R. and COEN, E. (2003). Genetic control of surface curvature. Science 299: 1404-7.

NEMHAUSER, J.L., MOCKLER, T.C. and CHORY, J. (2004). Interdependency of brassinosteroid and auxin signaling in Arabidopsis. PLOS Biol. 2: E258.

ODOM, D.T., ZIZLSPERGER, N., GORDON, D.B., BELL, G.W., RINALDI, N.J., MURRAY, H.L., VOLKERT, T.L., SCHREIBER, J., ROLFE, P.A., GIFFORD, D.K. et al. (2004). Control of pancreas and liver gene expression by HNF transcription factors. Science 303: 1378-81.

OHNO, C.K., REDDY, G.V., HEISLER, M.G. and MEYEROWITZ, E.M. (2004). The Arabidopsis $J A G G E D$ gene encodes a zinc finger protein that promotes leaf tissue development. Development 131: 1111-22.

OLIVERI, P. and DAVIDSON, E.H. (2004). Gene regulatory network controlling embryonic specification in the sea urchin. Curr. Opin. Genet. Dev. 14: 351-60.

PAYNE, T., JOHNSON, S.D. and KOLTUNOW, A.M. (2004). KNUCKLES (KNU) encodes a $\mathrm{C} 2 \mathrm{H} 2$ zinc-finger protein that regulates development of basal pattern elements of the Arabidopsis gynoecium. Development 131: 3737-49.

PELAZ, S., DITTA, G.S., BAUMANN, E., WISMAN, E. and YANOFSKY, M.F. (2000). B and C floral organ identity functions require SEPALLATA MADS-box 
genes. Nature 405: 200-3.

PELAZ, S., GUSTAFSON-BROWN, C., KOHALMI, S.E., CROSBY, W.L. and YANOFSKY, M.F. (2001a). APETALA1 and SEPALLATA3 interact to promote flower development. Plant J. 26: 385-394.

PELAZ, S., TAPIA-LOPEZ, R., ALVAREZ-BUYLLA, E.R. and YANOFSKY, M.F. (2001b). Conversion of leaves into petals in Arabidopsis. Curr. Biol. 11: 182-4.

PUTTERILL, J., LAURIE, R. and MACKNIGHT, R. (2004). It's time to flower: the genetic control of flowering time. Bioessays 26: 363-73.

RAMIREZ-PARRA, E., FRUNDT, C. and GUTIERREZ, C. (2003). A genome-wide identification of E2F-regulated genes in Arabidopsis. Plant J. 33: 801-11.

RAMIREZ-PARRA, E., LOPEZ-MATAS, M.A., FRUNDT, C. and GUTIERREZ, C. (2004). Role of an atypical E2F transcription factor in the control of Arabidopsis cell growth and differentiation. Plant Cell 16: 2350-63.

REID, J.L., IYER, V.R., BROWN, P.O. and STRUHL, K. (2000). Coordinate regulation of yeast ribosomal protein genes is associated with targeted recruitment of Esa1 histone acetylase. Mol. Cell 6: 1297-307.

REINKE, V. and WHITE, K.P. (2002). Developmental genomic approaches in model organisms. Annu. Rev. Genomics Hum. Genet. 3: 153-78.

REN, B., CAM, H., TAKAHASHI, Y., VOLKERT, T., TERRAGNI, J., YOUNG, R.A. and DYNLACHT, B.D. (2002). E2F integrates cell cycle progression with DNA repair, replication and $\mathrm{G}(2) / \mathrm{M}$ checkpoints. Genes Dev. 16: 245-56.

REN, B., ROBERT, F., WYRICK, J.J., APARICIO, O., JENNINGS, E.G., SIMON, I., ZEITLINGER, J., SCHREIBER, J., HANNETT, N., KANIN, E. et al. (2000). Genome-wide location and function of DNA binding proteins. Science 290: 2306-9.

REVILLA-I-DOMINGO, R. and DAVIDSON, E.H. (2003). Developmental gene network analysis. Int. J. Dev. Biol. 47: 695-703.

RIECHMANN, J.L. (2002). Transcriptional regulation: a genomic overview. In The Arabidopsis Book, (ed. SOMERVILLE, C. R. and MEYEROWITZ, E. M.). American Society of Plant Biologists, Rockville, MD.

RINN, J.L., EUSKIRCHEN, G., BERTONE, P., MARTONE, R., LUSCOMBE, N.M., HARTMAN, S., HARRISON, P.M., NELSON, F.K., MILLER, P., GERSTEIN, M. et al. (2003). The transcriptional activity of human Chromosome 22. Genes Dev. 17: $529-40$.

ROBBENS, S., KHADAROO, B., CAMASSES, A., DERELLE, E., FERRAZ, C., INZE, D., VAN DE PEER, Y. and MOREAU, H. (2005). Genome-wide analysis of core cell cycle genes in the unicellular green alga Ostreococcus tauri. Mol. Biol. Evol. 22: 589-597.

ROMBAUTS, S., FLORQUIN, K., LESCOT, M., MARCHAL, K., ROUZE, P. and VAN DE PEER, Y. (2003). Computational approaches to identify promoters and cis-regulatory elements in plant genomes. Plant Physiol. 132: 1162-76.

ROSSIGNOL, P., STEVENS, R., PERENNES, C., JASINSKI, S., CELLA, R., TREMOUSAYGUE, D. and BERGOUNIOUX, C. (2002). AtE2F-a and AtDP-a, members of the E2F family of transcription factors, induce Arabidopsis leaf cells to re-enter S phase. Mol. Genet. Genomics 266: 995-1003.

ROVEN, C. and BUSSEMAKER, H.J. (2003). REDUCE: An online tool for inferring cis-regulatory elements and transcriptional module activities from microarray data. Nucleic Acids Res. 31: 3487-90.

RUSTICI, G., MATA, J., KIVINEN, K., LIO, P., PENKETT, C.J., BURNS, G., HAYLES, J., BRAZMA, A., NURSE, P. and BAHLER, J. (2004). Periodic gene expression program of the fission yeast cell cycle. Nature Genet. 36: 809-17.

SABLOWSKI, R.W. and MEYEROWITZ, E.M. (1998). A homolog of NO APICAL MERISTEM is an immediate target of the floral homeotic genes APETALA3। PISTILLATA. Cel/ 92: 93-103.

SAKAI, H., KRIZEK, B.A., JACOBSEN, S.E. and MEYEROWITZ, E.M. (2000). Regulation of SUP expression identifies multiple regulators involved in arabidopsis floral meristem development. Plant Cel/ 12: 1607-18.

SCHIEFTHALER, U., BALASUBRAMANIAN, S., SIEBER, P., CHEVALIER, D., WISMAN, E. and SCHNEITZ, K. (1999). Molecular analysis of NOZZLE, a gene involved in pattern formation and early sporogenesis during sex organ development in Arabidopsis thaliana. Proc. Natt. Acad. Sci. USA 96: 11664-9.

SCHMID, M., UHLENHAUT, N.H., GODARD, F., DEMAR, M., BRESSAN, R., WEIGEL, D. and LOHMANN, J.U. (2003). Dissection of floral induction pathways using global expression analysis. Development 130: 6001-12.

SCHNABLE, P.S., HOCHHOLDINGER, F. and NAKAZONO, M. (2004). Global expression profiling applied to plant development. Curr. Opin. Plant. Biol. 7: 50-

SCHROEDER, M.D., PEARCE, M., FAK, J., FAN, H., UNNERSTALL, U., EMBERLY, E., RAJEWSKY, N., SIGGIA, E.D. and GAUL, U. (2004). Transcriptional control in the segmentation gene network of Drosophila. PLOS Biol. 2: E271.

SCOTT, M.P. (2000). Development: the natural history of genes. Cel/ 100: 27-40.

SEGAL, E., SHAPIRA, M., REGEV, A., PE'ER, D., BOTSTEIN, D., KOLLER, D. and FRIEDMAN, N. (2003). Module networks: identifying regulatory modules and their condition-specific regulators from gene expression data. Nature Genet. 34 : 166-76.

SHEN, W.H. (2002). The plant E2F-Rb pathway and epigenetic control. Trends Plant Sci. 7: 505-11.

SIMON, I., BARNETT, J., HANNETT, N., HARBISON, C.T., RINALDI, N.J., VOLKERT, T.L., WYRICK, J.J., ZEITLINGER, J., GIFFORD, D.K., JAAKKOLA, T.S. et al. (2001). Serial regulation of transcriptional regulators in the yeast cell cycle. Cell 106: 697-708.

STEVENS, C. and LA THANGUE, N.B. (2003). E2F and cell cycle control: a doubleedged sword. Arch. Biochem. Biophys. 412: 157-69.

STOLC, V., GAUHAR, Z., MASON, C., HALASZ, G., VAN BATENBURG, M.F., RIFKIN, S.A., HUA, S., HERREMAN, T., TONGPRASIT, W., BARBANO, P.E. et al. (2004). A gene expression map for the euchromatic genome of Drosophila melanogaster. Science 306: 655-60.

SUNG, S. and AMASINO, R.M. (2004). Vernalization and epigenetics: how plants remember winter. Curr. Opin. Plant. Biol. 7: 4-10.

TAKEDA, S., MATSUMOTO, N. and OKADA, K. (2004). RABBITEARS, encoding a SUPERMAN-like zinc finger protein, regulates petal development in Arabidopsis thaliana. Development 131: 425-34.

TURCK, F., ZHOU, A. and SOMSSICH, I.E. (2004). Stimulus-Dependent, Promoter-Specific Binding of Transcription Factor WRKY1 to Its Native Promoter and the Defense-Related Gene PcPR1-1 in Parsley. Plant Cell 16: 2573-2585.

VANDEPOELE, K., RAES, J., DE VEYLDER, L., ROUZE, P., ROMBAUTS, S. and INZE, D. (2002). Genome-wide analysis of core cell cycle genes in Arabidopsis. Plant Cell 14: 903-16.

VIDAL, M. (2001). A biological atlas of functional maps. Cel/ 104: 333-9.

VLIEGHE, K., VUYLSTEKE, M., FLORQUIN, K., ROMBAUTS, S., MAES, S., ORMENESE, S., VAN HUMMELEN, P., VAN DE PEER, Y., INZE, D. and DE VEYLDER, L. (2003). Microarray analysis of E2Fa-DPa-overexpressing plants uncovers a cross-talking genetic network between DNA replication and nitrogen assimilation. J. Cell Sci. 116: 4249-4259.

WAGNER, D., WELLMER, F., DILKS, K., WILLIAM, D., SMITH, M.R., KUMAR, P.P., RIECHMANN, J.L., GREENLAND, A.J. and MEYEROWITZ, E.M. (2004). Floral induction in tissue culture: a system for the analysis of LEAFY-dependent gene regulation. Plant J. 39: 273-82.

WANG, G., KONG, H., SUN, Y., ZHANG, X., ZHANG, W., ALTMAN, N., DEPAMPHILIS, C.W. and MA, H. (2004a). Genome-wide analysis of the cyclin family in Arabidopsis and comparative phylogenetic analysis of plant cyclin-like proteins. Plant Physiol. 135: 1084-99.

WANG, H., CARUSO, L.V., DOWNIE, A.B. and PERRY, S.E. (2004b). The embryo MADS domain protein AGAMOUS-Like 15 directly regulates expression of a gene encoding an enzyme involved in gibberellin metabolism. Plant Cel/ 16: 1206-1209.

WANG, H., TANG, W., ZHU, C. and PERRY, S.E. (2002). A chromatin immunoprecipitation (ChIP) approach to isolate genes regulated by AGL15, a MADS domain protein that preferentially accumulates in embryos. Plant J. 32: 831-43.

WANG, W. and CHEN, X. (2004). HUA ENHANCER3 reveals a role for a cyclindependent protein kinase in the specification of floral organ identity in Arabidopsis. Development 131: 3147-56.

WEIGEL, D., ALVAREZ, J., SMYTH, D.R., YANOFSKY, M.F. and MEYEROWITZ, E.M. (1992). $\angle E A F Y$ controls floral meristem identity in Arabidopsis. Cel/ 69: 843-59.

WEINMANN, A.S., YAN, P.S., OBERLEY, M.J., HUANG, T.H. and FARNHAM, P.J. (2002). Isolating human transcription factor targets by coupling chromatin immunoprecipitation and CpG island microarray analysis. Genes Dev. 16: 23544.

WELLMER, F., RIECHMANN, J.L., ALVES-FERREIRA, M. and MEYEROWITZ, E.M. 
(2004). Genome-wide analysis of spatial gene expression in Arabidopsis flowers. Plant Cell 16: 1314-1326.

WESTON, K. (1998). Myb proteins in life, death and differentiation. Curr. Opin. Genet. Dev. 8: 76-81.

WHITE, K.P., RIFKIN, S.A., HURBAN, P. and HOGNESS, D.S. (1999). Microarray analysis of Drosophila development during metamorphosis. Science 286: 217984.

WILLIAM, D.A., SU, Y., SMITH, M.R., LU, M., BALDWIN, D.A. and WAGNER, D. (2004). Genomic identification of direct target genes of LEAFY. Proc. Natl. Acad. Sci. USA 101: 1775-80.

WRAY, G.A., HAHN, M.W., ABOUHEIF, E., BALHOFF, J.P., PIZER, M., ROCKMAN M.V. and ROMANO, L.A. (2003). The evolution of transcriptional regulation in eukaryotes. Mol. Biol. Evol. 20: 1377-1419.

YAMADA, K., LIM, J., DALE, J.M., CHEN, H., SHINN, P., PALM, C.J., SOUTHWICK, A.M., WU, H.C., KIM, C., NGUYEN, M. et al. (2003). Empirical analysis of transcriptional activity in the Arabidopsis genome. Science 302: 842-6.

YANG, W.C., YE, D., XU, J. and SUNDARESAN, V. (1999). The SPOROCYTELESS gene of Arabidopsis is required for initiation of sporogenesis and encodes a novel nuclear protein. Genes Dev. 13: 2108-17.

ZHANG, J.Z. (2003). Overexpression analysis of plant transcription factors. Curr. Opin. Plant. Biol. 6: 430-40.

ZHANG, W., MORRIS, Q.D., CHANG, R., SHAI, O., BAKOWSKI, M.A., MITSAKAKIS, N., MOHAMMAD, N., ROBINSON, M.D., ZIRNGIBL, R., SOMOGYI, E. et al. (2004). The functional landscape of mouse gene expression. J. Biol. 3: 21.

ZIK, M. and IRISH, V.F. (2003). Global identification of target genes regulated by APETALA3 and PISTILLATA floral homeotic gene action. Plant Cell 15: 20722.

ZUO, J. and CHUA, N.-H. (2000). Chemical-inducible systems for regulated gene expression of plant genes. Curr. Opin. Biotechnol. 11: 146-152. 